\title{
Arquiteturas do corpo: máscaras e mascaramentos contemporâneos
}

\section{Body architectures: mask and contemporary masking}

\author{
Felisberto Sabino da $\operatorname{Costa}^{1}$
}

\section{Resumo}

Este artigo enfoca alguns apontamentos sobre máscara e mascaramento na cena contemporânea. Algumas passagens, certamente familiares a todos aqueles que trabalham nesse universo, estão impregnadas de tal forma em meu corpo - minha prática - que me aproprio delas como um ator, que, ao enfrentar diversas vezes um texto, acaba dizendo-as como se fora suas.

Palavras-chave: máscara; mascaramento; corpo; teatro contemporâneo.

\section{Resumen}

Este articulo se enfoca em algunos apuntes sobre la máscara y el enmascaramiento en la escéna contemporânea. Algunos pasajes ciertamente familiares a todos aquellos que trabajan en este universo, estan impregnados de tal forma en mi cuerpo, mi práctica de las que me apropio como actor, que al enfrentar un texto, acabasiendo como si fueran propias.

Palabras clave: máscara, enmascaramiento, cuerpo, teatro, contemporâneo.

\begin{abstract}
This article presents some notes on mask and masking in the contemporary theater.
\end{abstract} Some lines, which are certainly familiar to all those who work in such universe, are so embedded in my body - my practice - that I take them as an actor who takes the words of a text as his own.

Keywords: mask; masking; body; contemporary theater.

\section{Portais}

Principio este exercício de escrita acendendo uma vela preta, a qual representa o passado, o dia de ontem, posiciono-a ao lado de uma vela branca, também acesa, indicando o futuro, o dia seguinte. Diz-se que este era o costume nos lares romanos em homenagem a Janus. No espaço (intervalo) entre as duas velas, sobressai-se o que poderia nominar o presente, esse vazio (invisível) em que manifestamos nossos corpos e

\footnotetext{
${ }^{1}$ Universidade de São Paulo (USP). Professor livre-docente; Programa de pós-graduação em Artes Cênicas (PPGAC-ECA/USP). Possui experiência na área de Artes Cênicas, com ênfase em Dramaturgia, atuando principalmente nos seguintes temas: dramaturgia, atuação com objetos e teatro de animação.
} 
atuamos. A presença é também o espaço no qual passado e futuro perfuram o presente e se consomem. Talvez pudéssemos fazer uma aproximação com a noção de $M a$, presente na filosofia japonesa: o vazio necessário à criação. $M a$ seria a presença e o presente instaurados no corpo. À chama que se consome, que arde no fazer do corpo, (de)nomino mascaramento (ou máscara). O (de) ressaltado sinaliza os deuses e os demônios que permeiam a - nossa - história e afastam o tédio. Assim, mascaramento é pura consumação, ou seja, o corpo (como a vela) totalmente entregue ao ardor do momento.

Para além das categorias do teatro e da performance, a ideia de mascaramento flerta - ou se deixa flertar - com a performatividade e a teatralidade, ambas vistas como duas modalidades "que transbordam os marcos artísticos e são pensadas como partes de campos expandidos e no âmbito das reflexões sobre a subjetividade (DIÉGUEZ, 2015) ${ }^{2}$. Ainda trilhando esse chamamento, "o uso que Judith Butler faz do performativo para pensar o gênero como uma situação construída por repetição de atos, nos permite entender a performatividade como produção de atos e ações através dos quais nos expressamos e definimos no mundo"3, ou seja, o mascaramento se estende para além das artes da cena.

Sabe-se que os conceitos têm o propósito de petrificar os espíritos, e os mitos os desafiam. Entretanto, valho-me tanto de um quanto do outro para circunscrever o tema proposto, como Platão já fizera lindamente. Também é dito que - um - Deus, ao criar o - um - mundo, o fez por intermédio da fala. Deus abria a sua boca e dizia palavras que se convertiam em matéria. Partilhando esse artifício, emprego essas duas palavras mito e conceito - e crio mundos, matérias tecidas pela imaginação, ao escrever sobre um possível, ou seja, o mascaramento. Perfaço uma breve ficção para pensar o mundo da máscara inspirado pelas artes da cena produzidas atualmente.

A "lição que se pode tirar de um mito reside na literalidade da narrativa, não nos acréscimos que lhe impomos do exterior”, nos diz Ítalo Calvino (1990, p.17). Movido por essa passagem, teço alguns apontamentos sobre corpo, máscara e mascaramento, apoiado pela mitologia de modo bastante liberto. Ao assumir os meus passos, invoco dou voz - o-ao-meu "sangue latino" e convoco Janus ${ }^{4}$ para nortear a viagem.

\footnotetext{
2 Anotação de uma aula, em 11 de dezembro de 2014, durante a disciplina "Cenários Expandidos", ministrada por Ileana Diéguez, no Programa de Pós-graduação em Artes Cênicas da Escola de Comunicações e Artes da Universidade de São Paulo (ECA/USP).

${ }^{3}$ Idem.

${ }^{4} \mathrm{O}$ chamamento a Janus foi inspirado num discurso de Mário Buchbinder, em seu livro, "Poética do Desmascaramento".
} 
Força primordial, senhor do sol e guardião das portas e das entradas, divindade latina, Janus era considerado o pai dos deuses. É conhecido como o primeiro deus cultuado em cerimônia em Roma, até mesmo antes de os deuses gregos serem introduzidos, naqueles - nesses - tempos de contaminações - ou domínios - a que os homens estavam - são - sujeitos. Passagem, movimento, transição, tempo, mutação e limiar são palavras que incorporam tanto Janus quanto a máscara.

Janus pode ser considerado um corpo-máscara, deus bifronte que portava duas faces - olhares - em direções opostas. Ao trazer em si a ideia de duplo, estabeleço a relação com um corpo cênico, em que a palavra outro pode ser lida tanto como alteridade quanto hétero - diferente. As duas faces de Janus dizem respeito ao passado e ao futuro e ouso-me a dizer à máscara e à contramáscara, àquilo que revela e esconde, àquilo que tensiona os olhares. Pode se apresentar como um homem jovial e belo (futuro) e como um ancião de olhar profundo (o passado), mas poderíamos inverter esses tratados, trair esses ritos e afirmar que é um deus da reversibilidade. Janus é o equivalente masculino da deusa Jana, e conforme Buchbinder, seu nome provém de Diana, cuja raiz é dius ou dium, significando luminoso. Deriva igualmente de div (divisão) ou di (duplo), o que remete a separação, o diálogo e o diafragma (1996, p.222). Ele é a cisão da pessoa, a multiplicidade de aspectos da máscara e do mascaramento. Vestindo-me com a pele de Agamben, diria: "é também aquele que dividindo e interpolando o tempo está à altura de transformá-lo e colocá-lo em relação com os outros tempos, de nele ler de modo inédito a história" (2009, p.72). Dessa forma, o mascaramento seria o corpo do "momento agora", situado entre o "não mais" e o "ainda não".

Um corpo-máscara constitui presentidade que se dispõe em relação a outros tempos, é a presença e o presente que interagem com a ausência e a memória. $\mathrm{O}$ mascaramento revela-se contemporâneo no sentido de que "é aquele que mantém firme o olhar no seu tempo para nele perceber não as luzes, mas o escuro. [... Perceber no escuro do presente essa luz que procura nos alcançar e não pode fazê-lo" (AGAMBEN, 2009, p.62-64).

Deus do firmamento luminoso, das origens, do princípio de tudo o que existe, Janus põe em jogo a dificuldade dos começos e o retorno à origem. Ele abria o céu à luz e era quem o fechava. Presidia as portas privadas e públicas, reais e ideais. $\mathrm{Na}$ vida privada, era o deus das aberturas por onde a luz entrava nas casas. Assim, Janus é a abertura que habita um corpo-máscara. Tal como "a casa é o corpo", como dissera 
Lygia Clark, "a máscara é o corpo". Infiltrar-se nessa arquitetura é dispor-se, como na obra de Clark, a perder o equilíbrio cotidiano, a lidar com o escuro, a ver e ser visto do exterior, adentrar a boca na qual a pessoa entra na germinação, realizando um passeio que envolve os sentidos (1980, p.33).

Saturno possivelmente dotou Janus com o atributo de ver tanto o passado quanto o futuro, daí o olhar para frente e para trás. A experiência de Lygia Clark invoca a gestação e podemos associá-la às duas companheiras da deusa Carmenta: antevorta (futuro) e postvorta (passado), temporalidades que presidem o nascimento na Roma antiga $^{5}$ e que podemos associar a Janus. Nascer é buscar uma singularidade não destituída de uma relação com o oceano de imagens arquetípicas, um universo em que podemos nos alimentar do mito e da potência do inconsciente ao qual acede a máscara. Para Jung,

\footnotetext{
o inconsciente é como o Janus bifronte; por um lado, seus conteúdos apontam para trás, em direção a um mundo do instinto pré-consciente e pré-histórico; por outro, antecipa potencialmente um futuro, devido a uma prontidão instintiva dos fatores determinantes do destino. Um conhecimento completo de um traçado de fundo existente desde o início de um indivíduo poderia ser em grande parte a condição de possibilidade da predição do seu destino. (2002, p.272-273).
}

A direção a um mundo primevo pode nos levar à infans, à criança anterior à linguagem. São diversos os exercícios com a máscara que buscam a "fala" antes da palavra, um corpo que descobre os seus mundos. Não me refiro ao jogo do silêncio à fala, como em algumas pedagogias com a máscara, porém de um mundo anterior, no qual se assenta no caos que antecede o conceito.

Como deus da transição é um ente que precede. Ele pode estar relacionado às margens ou ao espaço intervalar entre uma e outra. De Janus vem janeiro e, como diz a sabedoria popular, esse mês traz um pouco do passado e a promessa de um futuro. Janus presidia o ano, os meses e os dias. Desse modo, no começo de uma jornada invoca-se Janus - deus dos portais e das transições (metamorfoses), dos inícios e fins. A ele também está associada a mudança entre a vida primitiva e a civilização, o obscurantismo e a ciência e o campo e a cidade. Os soldados que saíam para as campanhas eram conduzidos ao portal do santuário por onde deveriam passar. Trabalhar

\footnotetext{
5 “Antevorta" e "Postvorta" tinham dois altares em Roma e eram invocados por mulheres grávidas como divindades protetoras contra os perigos do parto.
} 
a máscara requer rituais de passagem, assim como em Janus. Não necessariamente solenes, podem ser pequenas ações, similarmente ao nosso cotidiano.

A dualidade inscreve-se nos escassos mitos conhecidos, os quais apresentam Janus como humano e também como um deus primevo, amorfo inicial (caos). Janus é deus e é homem. Oriundo da Tessália, tal como Dioniso/Baco, era um estrangeiro que chegava a um novo território (Lácio) e conduzia o povo a uma nova realidade/tempo. Tido como o senhor do desenvolvimento cientifico, da criação de leis, do aprimoramento do cultivo e da cunhagem das primeiras moedas correntes, Janus transformou o território que atravessou. É possível afirmar que vestir uma máscara é receber a visita de um estrangeiro, transitar entre a ciência e a arte, o conhecido e o desconhecido, transformar e ser transformado, penetrar e ser penetrado, dar voz a um corpo (cênico) que afronta a morte e que arde alegremente ante o trágico vivido.

Divindade das mudanças e das tradições, Janus era adorado no primeiro dia dos meses, nas épocas de plantio, das colheitas, dos casamentos, dos nascimentos, enfim, dos acontecimentos considerados importantes na vida das pessoas, nos momentos de transição e nas escolhas que mudam os cursos da vida. As relações que podemos tecer com a máscara seriam sintetizadas na imagem da porta sempre aberta para os dias de ontem e para os dias que ainda estão por vir. Janus e mascaramento tecem um diálogo nunca terminado. Deus dual - não dualista -, ao trazer uma face voltada para a luz e a outra para as trevas, gera polaridades que não devem ser pensadas de forma estanque. Antes, deve-se atuar como a própria chave que ele porta, pois ela abre - é - o espaço que gera um e outro. Portanto, novo e velho, passado e futuro, dia e noite dançam a mesma dança, a mesma música. Assim, o território da máscara seria o espaço do girar a chave.

Conta-se que, das duas faces de Janus, uma falava uma verdade enquanto a outra desdizia-a, o que nos remete à confusão de uma pessoa frente à escolha. Janus, deus das indecisões ou indecidibilidade. Se, por um lado acalentava, por outro trapaceava. Um transitar constante entre um e outro lado. Por isso, adentramos o terreno da ambiguidade.

Nesse trajeto que venho construindo, valho-me de imagens metafóricas, nomeações ou até mesmo divagações desse possível deus que encarna o oculto/escondido, a verdade/mentira e o caos interno/externo. Trata-se de um deus que pelas qualidades que lhe são atribuídas nomeia, atualmente, corpúsculos surfactantes: a 
partícula Janus. Esta é uma substância parcialmente hidrofílica e parcialmente hidrofóbica, parte atrai e parte rejeita a água. Assim, entramos num domínio em que é permitido navegar em outras direções. Partículas Janus são úteis para a fabricação dos conversores de energia solar; das telas de computador flexíveis com a espessura de uma folha de papel ou a fim de compor dispositivos para a administração seletiva de medicamentos. Servem tanto à constituição de corpos ciborgues, mediante a inserção de próteses, como de aditivos químicos que estimulam ou modificam o corpo.

Sob o signo de Janus, máscara e mascaramento se apresentam como portais. Portas que se abrem em duas - ou mais - direções: dentro e fora; o limi(n)ar. Mascaramento como jogo e alteridade que põe em questão a identidade. Máscara como “a alegre negação da identidade e do sentido único; negação da coincidência estúpida consigo mesmo, [...] da violação das fronteiras naturais" (BAKHTIN, 1987, p.35). É um mascaramento contemporâneo que não "adere estreitamente ao seu tempo, que não coincide perfeitamente com este, nem está adequado às suas pretensões”, resultando numa "singular relação com o próprio tempo, que adere a este e ao mesmo tempo toma distância” (AGAMBEN, 2009, p.59). Sob esse olhar, máscara é diálogo.

A essa altura do texto, outra divindade entra em cena, o Genius, deus que preside os nascimentos, pois, no processo constitutivo de uma máscara, seja mascareiro seja atuante, seria interessante confiá-la a Genius na hora de seu nascimento. Segundo Agamben, na relação secreta que cada um deve saber cultivar com o próprio Genius, deve-se "ser condescendente e abandonar-se a ele" (2007, p.16), uma vez que "é essa presença inaproximável que nos impede que nos fechemos em uma identidade substancial. É Genius que rompe com a pretensão do eu bastar-se a si mesmo” (2007, p.17). Nesse sentido, ele é um provocador, um guardião que abala a bastança da máscara. Viver com Genius "significa, nessa perspectiva, viver na intimidade de um ser estranho, manter-se constantemente vinculado a uma zona de não conhecimento" (2007, p.17). Mascarar-se é habitar tal território, adentrando em zonas desconhecidas. Confeccionar a máscara, ou invocar o mascaramento, traz como premissa a fricção com Genius que a cada a[u]tor é dada a enfrentar.

Em templos dedicados a Janus, haviam portas voltadas para os lados em que o sol e a lua nasciam e para onde esses astros desapareciam no horizonte. As portas permaneciam fechadas em tempos de paz, uma espécie de película que a protegia das injunções externas. Um corpo-máscara não se conforma num território apascentado, não 
se apazigua num fechar em si, há sempre uma tensão que o faz vibrar, há sempre um estrangeiro que o perturba, bate à porta e o convida a adentrar a 'zona de não conhecimento'. Permanecer somente no conhecido é lidar com uma máscara morta.

\section{Corpo, Máscara e Mascaramento}

Para além da oposição esconder-revelar o corpo, que é atribuída ao uso da máscara, outras possibilidades podem advir da relação que se instaura ao vesti-la. Mascaramento é um fenômeno mutante tal como Zeami declara em relação ao teatro No: "uma nova flor é criada em resposta à mudança dos tempos" (1984, p.161). Nesse sentido, é um processo histórico, há sempre que moldar novas chaves para acedê-lo. Mais que se ater à fricção entre real e ficcional, o mascaramento se situa na ambiguidade dessas fronteiras. Não se trata tanto de buscar relações entre um e outro, mas de viver essa tensão.

Um corpo-máscara pode adentrar o território de uma linguagem específica ao experimentar a commedia dell'arte, o clown, o bufão, o topeng ou o nogaku. Essas práticas mascaradas não se vinculam somente à utilização de um objeto, mas a mergulhar o corpo num caudal em que a máscara é um de seus constituintes. Há determinados códigos, leis ou procedimentos que estão associados a essas artes do corpo quanto à utilização da máscara. Poderíamos nos aventurar a dizer que há certo modo de trabalhá-la, certas regras e convenções mais ou menos fixadas que as perpassam. $\mathrm{O}$ mesmo pode acontecer em determinadas pedagogias na ambiência escolar técnica ou universitária. Entretanto, há possibilidades de aproximação ao objetomáscara ou ao conceito-máscara que não se atêm a uma certa 'sacralização' dos procedimentos e rompem deliberadamente imposições e tratados, traem os ritos. Desse modo, há encontros que possibilitam engendrar espaços de desafios, geografias da outridade que nos endereçam ao mascaramento.

Máscara e mascaramento às vezes podem ser sinônimos, mas podem também instaurar perspectivas distintas, nas quais o termo mascaramento amplia a sua paleta, distanciando-se da noção usual de máscara. O mascaramento contemporâneo opera em conformidade com a desconstrução derridiana, em que a lógica binária é problematizada. Não se busca apenas esconder ou revelar um corpo, porém ativá-lo, redimensioná-lo, colocá-lo em questão frente às injunções a que somos submetidos na contemporaneidade. Às vezes, não se trata da arte concebida como proposta estética, 
mas da própria arte-vida que é levada a um grau de estranheza e estranhamento do corpo, à procura de estados corporais, intensidades que chacoalham a existência seja ela qual for. O mascaramento evoca o caos (Janus), na dimensão poética posta em Ovídio (2010), a respeito da criação. Este é um paradoxal encontro de realidades contrapostas.

Na figura de Janus, a tensão que emerge pela ausência de um olhar frontal cria um vazio, uma ausência entre os rostos virados em direções contrárias. Entre um e outro olhar há um terceiro 'rosto' que nos convida a observar não a nossa imagem no outro, não um outro idealizado, mas o outro como um legítimo outro. "A aceitação do outro como um legítimo outro não é um sentimento, é um modo de atuar" (MATURANA 1998, p.66). Destarte, outra conceituação para mascaramento seria: experimentar diferenças. Nessa busca, o mascaramento não descarta a ironia, que "tem a ver com o humor e o jogo sério" (HARAWAY, 2009, p.35). Partilha a ideia de um corpo ciborgue, "espécie de criatura de um mundo pós-gênero, [...] criatura de realidade social e também uma criatura de ficção" (HARAWAY, 2009, p.36). Portanto, o mascaramento insere-se num terreiro que se caracteriza, minimamente, por três rupturas de fronteiras cruciais, como apontadas por Haraway: entre o humano e o animal; o animal-humano (organismo) de um lado e a máquina de outro; e a imprecisão entre o físico e o não físico (2009, p.41 - 42).

Um mundo de ciborgues pode significar realidades sociais e corporais vívidas, nas quais as pessoas não temam sua estreita afinidade com animais e máquinas, que não temam identidades permanentemente parciais e posições contraditórias. A luta política consiste em ver a partir de ambas as perspectivas ao mesmo tempo, porque cada uma delas revela tanto dominações quanto possibilidades que seriam inimagináveis a partir do outro ponto de vista. Uma visão única produz ilusões piores do que uma visão dupla ou do que a visão de um monstro de múltiplas cabeças. (HARAWAY, 2009, p.46).

Como sabe-se, a máscara não se vincula necessariamente à realidade de um objeto plástico. Além disso, nem sempre está em jogo a (re)presentação de um personagem, de uma figura, de um ser ficcional ou que tais. Há situações nas quais a máscara se configura como um texto visual ou adentra uma amplitude conceitual ainda mais vasta que poderíamos nominar mascaramento. Para Sanchez, a performatividade nos aproxima do corpo de uma maneira muito diferente da teatralidade $(2011$, p.28). Desse modo, é possível destacar que: 
A teatralidade é o território da máscara. A performatividade é o do mascaramento, do trânsito constante da sinceridade à máscara e da máscara à sinceridade. Ainda que há bastante tempo aprendemos que a sinceridade, como a nudez, não significam nada por si mesmas; que a nudez já não significa liberdade do mesmo modo que a sinceridade tampouco significa verdade, nem sequer honestidade (SANCHEZ, 2011, p.28).

Em determinados casos, mais que a máscara em si, o que nos interessa é o seu discurso, é experienciar o que o mascaramento pode gerar. Quando se veste uma máscara, possibilidades brotam deste ato, o qual tanto pode vir a ser disfarce como afirmação. Mais que imagem, mascaramento é o gesto na acepção de Agamben (2008), e o ato conforme nos propõe Bakhtin (1977). Sob essa perspectiva, o mascaramento nas artes da cena pode contaminar - e contamina - outros aportes que envolvem o corpo e a sua construção social: máscaras societais, persona, fachada ou liminaridade são alguns dos potenciais conceituais que invadem o olhar de um e de outro, provocando fricções entre a arte e a vida. Ao flertar com a teoria queer (quir), o mascaramento contemporâneo (a máscara) distancia-se dos padrões estabelecidos e propicia fissuras no mundo naturalizado da cena, buscando ler "as marcas daquilo que já é o fim do corpo, tal como este foi definido pela modernidade" (PRECIADO, 2015, p.2). Máscara e mascarado são termos da cena e xingamentos. Responder a essas questões é posicionarse.

Em suas memórias quando estudante, Miskolci localiza no pátio da escola, lugar de brincadeiras, o local social em que 'meninos robustos' empurravam 'meninos fracos' para a fila feminina, 'espaço desqualificado em si mesmo' (2012, p.9). O mascaramento, no sentido expandido, põe em jogo o espaço em que a heteronormatividade é o modelo e sinaliza "para o estranho, para a contestação, para o que está fora-do-centro, excêntrico" $(2012$, p.10). Na perspectiva ameríndia, se o que conecta todos os seres vivos é a humanidade, o que nos distingue é o corpo-veste. Assim, o mascaramento (esse estranho fora-do-centro) opera na multiplicidade, na fluidez das identidades-veste, dos corpos transviados e desviantes.

O mascaramento poderia ser visto como um ato transformativo do corpo, tanto no espaço privado quanto no público, visando o olhar e o olhar-se, sair de si. Narciso, ao deparar-se com a sua imagem (rosto) na superfície espelhada da água, quando quis pegá-la para si, morreu afogado. Na tentativa de diminuir a distância entre seu corpo (face) e a imagem, Narciso empreendeu um ato antimáscara, ao querer colar à sua pele uma face (outro) similar à sua. 
Os mestres pesquisadores do campo da máscara afirmam que é necessário haver distância para que se possa haver jogo. Nesse sentido, a máscara funda-se no diálogo, o que implica contato e separação, ela lida com a diferença. A sedução da máscara se instaura na diferença, requer a outridade, pois é pobre "a ideia de que a sedução se funda na atração do mesmo, numa exaltação mimética de sua própria imagem ou no espelhismo ideal do parecido" (BAUDRILLARD, 1981, p.67). Frente ao espelho d'água, Narciso aplacou sua sede: 'sua imagem já não é “outra', é sua própria superfície quem o absorve, quem o seduz, de tal modo que somente pode aproximar-se sem nunca ir más além, pois não há mais além como tampouco há distância reflexiva [ou de jogo] entre Narciso e sua imagem" (BAUDRILLARD, 1981, p.68).

O outro, no universo da máscara, refere-se também ao espectador, o qual partilha de sua constituição. Atuar com a máscara é compor o território de afetos que conecta atuante e espectador. Vestir uma máscara é um ato de compartilhamento entre corpos: atuante e espectador. Abrir os olhos e os ouvidos do público, durante a atuação de uma peça $N o$, é fazer o espectador experimentar um estado-corporal-máscara, por intermédio de um admirável espanto. No teatro No, 'abrir os ouvidos' refere-se a "uma mistura de entendimento/compreensão verbal e sensação musical numa fonte sonora/aurática de apreciação" (ZEAMI, 1984, p.158). Desse modo, 'abrir os olhos' é o momento em que sensações profundas são experienciadas, um momento de intensa troca entre o ator e o público. Quando os 'seus olhos estão abertos', os espectadores “recebem uma extraordinária impressão através das qualidades estéticas relacionadas à dança e ao movimento" (ZEAMI, 1984, p.158). Assim, 'abrir os ouvidos' está associado à escritura/texto da peça, enquanto 'abrir os olhos' à habilidade do ator, porém ambos estão conectados ao conceito máscara, o que deve acontecer com todos os elementos em jogo.

A natureza da máscara diz respeito não tanto a estar no espaço, mas a criar locais provisórios em suas ações. Durante o processo de atuação, o atuante-máscara cria espaços que se esvaem à medida que não são mais necessários. Um corpo-em-máscara elege os espaços de suas experiências sucessivas, seja na cena seja na convivência urbana. A máscara é também o lugar dos encontros heterotópicos, nos quais não se está, mas, por algum designo, tece-se algum contato. Assim, "o meu corpo é como a Cidade de Deus, não tem lugar, mas é de lá que se irradiam todos os lugares possíveis, reais ou utópicos" (FOUCAULT, 2015, p.4). De modo parecido ocorre com o tempo (heterocrônico), que também se instala como duração.

Valendo-me de uma quase-ficção (ou quase-realidade), no mascaramento, a lida com o tempo não é a dos(as) 'velhos(as) senhores(as)' que se queixam de um passado vivido, declarando: 'no meu tempo era melhor' ou 'éramos mais avançados'. A lida é a dos 'velhos(as) senhores(as)' que se munem de um material bélico e almejam explodir aquilo que pretende ser a repetição vazia, ou seja, a reiteração do mesmo. Recorrendo a 
uma imagem vista numa noite qualquer, a liga com o tempo seria Sandra Rosa Madalena, cantada por um erê, num bar-caraoquê de uma noite fervida, numa cidade qualquer.

O mascaramento é arquitetura política do corpo, é cantar possibilidades, é tecer corpos e identidades transitórias. A perspectiva aqui enfocada, embora possa tangenciar outros campos, funda-se, como mencionado, nas artes da cena. Vista não como um mapa, um espaço (abstrato) demarcado, mas um terreiro (território) cujas fronteiras são maleáveis. À ideia de território associa-se o habitar. Logo, compor um território é habitá-lo corporalmente, é lidar com as fronteiras. O mascaramento se refere ao acontecimento do - e no - corpo posto em diálogo com territórios ao qual liga o tempo. Um corpo que se distancia de uma imposição que tenta configurar em sistema hierárquico de órgãos. É um dizer contaminado do indizível, um corpo anarco-desejante que não se furta às misturas, hibridações, heterogeneidades e sujeiras.

O indizível não quer dizer o inalcançável, mas o imponderado, aquilo que se manifesta mais além da fronteira, das pregas corporais. Não somente falar, mas o (pro) ferir, atravessar (rasgar) o corpo com sua potência sonora. Nessa perspectiva, a utilização da máscara é borrada, e não se subordina a regras ou postulados. $\mathrm{O}$ atuante a investe de um jeito 'negligente' que não se nutre, necessariamente, pela técnica estabelecida, embora possa reconhecê-la como uma contribuição inestimável. Máscara como objeto que revela a sua materialidade pura, a sua forma, os seus limites, que não se interessa em ser animada, mas ser 'coisa', ser um dizer atravessado pelo mundo prenhe de sujidade. Máscara-corpo que copula com os corpos. O mascaramento é um corpo promíscuo, no sentido de misturado, baralhado ou público. Um corpo poético como "lugar de entrelaçamento entre o esquema corporal (substrato biológico) e a imagem inconsciente do corpo (pulsão, desejo). Entremeado no qual estão presentes a carne e o espírito" (BUCHBINDER, 1996, p.75). É um corpo sedutor.

Ao abordar a sedução sob o influxo do mundo contemporâneo, Baudrillard (1981) recorreu ao seu significado latino, seducere, que significa afastar da via. Mascaramento é sedução ao afastar-se da via cotidiana, ao promover um desvio real do nosso imaginário diário. Desse modo, mascaramento seria um deslocamento do corpo positivado:

E nossas tentativas de positivar o mundo, dar-lhe um sentido unilateral, bem como toda a imensa organização da produção, tem, sem dúvida, a finalidade de eliminar, de abolir esse terreno 
indiscutivelmente poderoso maléfico da sedução. Pois [...] o mundo da produção tem o poder, mas a potência está do lado da sedução. (BAUDRILLARD, 2007, p.26).

Quando uma máscara é esculpida, lida-se com a transformação da matéria, estabelecendo-se uma rede intricada (forças visíveis e invisíveis) que se plasma no objeto. Algumas dessas ações encontram-se na pele da máscara, outras permanecem invisíveis e são ativadas quando postas em movimento. Cada máscara confeccionada traz uma história, um percurso condensado em sua feição que se dá a ver. Há uma carga de afetos manipulada e organizada pelo mascareiro, que gera um entrelaçamento complexo, uma arquitetura que convida o corpo a habitá-la. Uma boa máscara se constrói pelo diálogo com o mundo, por um jogo de tensões entre o passado e o futuro apostos na imagem. Como Janus, a máscara é um portal aberto a possibilidades de inúmeras figuras, que o corpo as faz singular por meio do diálogo. Assim como um texto, cada máscara tem um ritmo particular, que se traduz na escritura visual elaborada por aquele que a materializa.

As qualidades materiais da máscara interagem com os estados corporais do atuante e com o espectador, ativando um entremeado de forças que se fazem visíveis pelo movimento. "A ação arquitetônica [da máscara] está situada sempre entre a liberdade da imagem e o domínio sistemático de sua materialidade” (ITO, 2000, p. 201). Assim, a máscara é tanto a fixidez (permanência) dos traços, em sua feição, revelada pelos volumes, curvaturas, ângulos, linhas quanto maleabilidade, metamorfose que advém do movimento. "Essa permanência no tempo, essa perduração do objeto, essa imortalidade é um elemento a mais que conecta a máscara com o sinistro" (BUCHBINDER, 1996, p.138).

Na maquiagem-máscara, ao contrário, os traços inscritos na pele tornam-se menos duráveis. Diferentemente da tatuagem, não se configura como uma imagem que perdura no corpo. Experiências com argila e outros materiais maleáveis podem gerar sobre o rosto uma performatividade em que a feição é plasmada pelo atuante, e a cada instante em que brota a face certo mistério acontece, proveniente da manipulação.

Usar máscaras, maquiar-se, tatuar-se, não é exatamente, como se poderia imaginar, adquirir outro corpo, simplesmente um pouco mais belo, melhor decorado, mais facilmente reconhecível. Tatuar-se, maquiar-se, usar máscaras, é, sem dúvida, algo muito diferente; é fazer entrar o corpo em comunicação com poderes secretos e forças invisíveis. A máscara, o sinal tatuado, o enfeite colocado no corpo é toda uma linguagem: uma linguagem enigmática, cifrada, secreta, 
sagrada, que se deposita sobre esse mesmo corpo, chamando sobre ele a força de um deus, o poder surdo do sagrado ou a vivacidade do desejo. A máscara, a tatuagem, o enfeite coloca o corpo em outro espaço, o fazem entrar em um lugar que não tem lugar diretamente no mundo, fazem desse corpo um fragmento de um espaço imaginário, que entra em comunicação com o universo das divindades ou com o universo do outro. (FOUCAULT, 2015, p.3).

O mistério está presente no contato com a pele de corpos atravessados pela máscara através dos afetos, que é uma espécie de repositório que impregna a matéria. Desse modo, o objeto-máscara é um entranhado - um emaranhado - de memórias, rastros de outros corpos que o vestiu ao longo de sua existência, pois a máscara, como o corpo, morre, e, portanto, não sabemos mais no que ela advém. Reitero que o objetomáscara não se confunde com a máscara, que se torna corpo quando em movimento, moveres do corpo que se estendem do micro - aparentemente estático - ao macro. A sua existência implica tais moveres de toda espécie. Talvez devido à sua extrema solidez, os gregos acreditaram que a pedra não tivesse alma, relegando-a ao estatismo, porém, este é apenas aparente. Há algo que acontece na visível imobilidade do corpo. O escudo de Perseu desvia o olhar da Górgona para que possa ser corpo-máscara, possa se mover, não se converter em corpo-pedra, solidificando os espaços necessários (a respiração) ao movimento. Assim, o escudo-espelho de Perseu é uma estratégia desviante do corpo.

Há múltiplas formas de engendrar estratégias do corpo quando em máscara. O ator Keiichiro Tsuchiya, ao comentar o 'desconforto corporal' - ansiedade - instaurado pela limitação da visão em virtude da utilização de máscara, aborda uma postura (kata) em que a parte superior do corpo inclina-se levemente para frente, ao mesmo tempo em que executa uma leve curvatura do plexo projetando-o à frente. Segundo ele, essa postura "rechaça a ansiedade pela força que engendra em seu interior" (apud ITO, 2000, p.80). Tsuchiya esclarece que a dança do No não é apenas mover-se pelo palco. O ator se movimenta em conformidade com a força que nasce das posturas tomadas. A dança ocorre por essa 'corrente de forças' que ativa o corpo-máscara do atuante lidando com o exíguo espaço do palco. Essa mesma ideia de posturas ativadoras do corpo, em outros contextos, pode ser pensada para as partituras do Arlecchino da Commedia dell'arte, do Mateus e do Bastião do Cavalo Marinho ou do Cazumba do Bumba meu Boi maranhense. As partituras corporais não são formas esvaziadas, mas vazios que o corpo atuante habita, colocando em jogo a condensação energética que a forma propicia. A postura requer a proposição de um agente, dado que podemos considerá-la máscara. Dessa forma, as estratégias do corpo para a constituição de uma máscara trabalha na 
perspectiva do desvio, uma estratégia que ainda revela sua potência frente aos olhares escusos de nosso tempo. Numa possível síntese, poderíamos dizer que o mascaramento é a arte do olhar, do saber olhar. Arte do desvio estratégico, da sedução, do medo (temor) que não nos paralisa ou petrifica, mas que nos move, no sentido de pôr em movimento e também de comover, saber lidar com o interdito, com o mistério que demanda uma chave para adentrá-lo.

As transformações do corpo na ambiência hodierna das cidades também podem operar segundo a ótica do desvio. Toyo Ito (2000, p.47) nos chama a atenção para a constituição de uma sensação androide que os habitantes urbanos já dispõem. De um corpo nômade que flutua pelo espaço urbano, na torrente ida e vinda dos automóveis, permeado por um fluxo de correntes magnéticas invisíveis, imerso na sombra das árvores em meio aos arranha-céus:

\footnotetext{
Nossa pele, sem nos darmos conta, começa a perceber as matérias inorgânicas e artificiais, como o metal ou plástico, com mais naturalidade que os materiais naturais. Também começa a perceber o espaço fictício e imaginário [da cidade] como algo mais confortável que o espaço real. A cidade recorre ao corpo androide, oferece um espaço experimental simulado, fragmentado e cada vez mais fechado, e segue formando androides adequados para esse cenário. (ITO, 2000, p.64).
}

Nos dizeres de Ito, esse fenômeno não se limita apenas ao espaço comercial da cidade, e ocorre de forma similar nas moradias. "Os fragmentos da casa, realizados estrategicamente nos espaços comerciais, são reexportados de volta para as moradias que passam a ser configuradas como uma colagem do espaço urbano simulado" (2000, p. 64). Ainda conforme o arquiteto, a tecnologia cria ficção, por isso nos comportamos como atores ou atuamos como espectadores perante os aconteceres das cidades material e fenômeno. A mesa da sala de refeições, onde antes se reunia a família, converteu-se em uma ida a um restaurante, no qual a pessoa se porta "como se fosse a melhor família, confirmando sua existência ante os olhos do público" (ITO, 2000, p.64). Portanto, o traspasse entre ficção e realidade não diz respeito apenas às artes da cena e a teatralidade se instala no cotidiano das cidades, notadamente, nos corpos que habitam as metrópoles-fenômeno.

O mascaramento busca um corpo utópico e vai de encontro às utopias que ‘nasceram para apagá-lo’ (FOUCAULT, 2015): corpo-incorpóreo, corpo-promessa em realidades pós-morte e corpo-metafísico sob o domínio da alma. Ele afirma-se como 
corporalidade, porém, como menciona Foucault, eis que o - meu - corpo em virtude dessas utopias desapareceu:

\begin{abstract}
Desapareceu como a chama de uma vela que alguém sopra. A alma, as tumbas, os gênios e as fadas se apropriaram pela força dele, o fizeram desaparecer em um piscar de olhos, sopraram sobre seu peso, sobre sua feiura, e me restituíram um corpo fulgurante e perpétuo. Mas, meu corpo, para dizer a verdade, não se deixa submeter com tanta facilidade. Depois de tudo, ele mesmo tem seus recursos próprios e fantásticos. (FOUCAULT, 2015, p.2).
\end{abstract}

Entre tais 'recursos próprios e fantásticos', situa-se o mascaramento, não como promessa, mas como ação no aqui e agora, como uma possibilidade de experimentar estados corporais intensos sem o auxílio de subterfúgios miraculosos. "Para que eu seja utopia, basta que eu seja um corpo" (FOUCAULT, 2015, p.3), um corpo em ato no território do mascaramento, de vestir possibilidades. Pode-se afirmar que mascaramento é a inconstância de um corpo selvagem, que não se sujeita à solidez do mármore e prefere a versatilidade da murta, tal como apontado no pensamento ameríndio analisado por Viveiros de Castro (2002). Apropriando-me das passagens contidas no livro deste autor, ligeiramente modificadas, vestir uma roupa-máscara seria menos ocultar uma essência, sob uma aparência qualquer, que ativar os poderes de um corpo-outro. São corpos que, tal como o diálogo, são realizados na fronteira.

"Não há nem primeira palavra nem derradeira palavra", nos diz Bakhtin, pois os contextos do diálogo não têm limite. Estendem-se ao mais remoto passado e ao mais distante futuro. Sob essa perspectiva, o mascaramento engloba o sensível (mundo vivido) e o inteligível (elaboração segunda da percepção).

Um ato de nossa experiência concreta, é como Jano, que tem duas faces. Ele olha em duas direções opostas: olha para a unidade objetiva de um domínio da cultura e olha para a ocorrência única nunca repetível da vida atualmente vivida e experimentada. (BAKTHIN, 1977, p.8).

Há uma parcela que é fixa e outra que não pode ser repetida na máscara. Esses dois aspectos se contaminam e se transformam, dado que aquilo que não acontece outra vez afeta o estável. Desse modo, o mascaramento é dialogismo, ele se faz com o outro em diversas modalidades. Nessa trilha Bakhtiniana, podemos defini-lo como ato ético, que nos implica de alguma forma. Ética, ethos, persona, máscara, pessoa, mascaramento ou personagem se conectam enquanto construção de um ser. Aristóteles, em sua Poética, aborda a construção de um comportamento, de um ethos relativo à 
configuração de um ser ficcional. Retornando ao mascaramento, estética $=[$ est]ética, pois não se trata apenas de um estilo, de um modo de grafar um nome, mas de uma conjunção, uma eticidade que podemos atribuir a uma máscara. Mais que a sua fisicalidade, o que está em jogo é como ela se (a)presenta, como interpela o outro, o corpo.

Se "o modelo ideal de arquitetura do Renascimento se apoiava na concepção estática do corpo, em que pode apoiar uma arquitetura [uma máscara] que considera o corpo humano como um sistema de fluidos?" (ITO, 2000, p.71). Foucault (2015) salientou que os gregos não tinham uma palavra para designar a 'unidade do corpo' (2015, p.4). Assim, Homero, ao se referir ao corpo de um herói, nomeia braços, pernas ágeis ou peitos valorosos. Por sua vez, Yoshito $\mathrm{Ohno}^{6}$ afirma que a língua japonesa possui quatro termos para designar o corpo. Desse modo, trabalhar a máscara - o mascaramento - é conhecer o corpo que se coloca em ato. Reitero que o mascaramento aqui tratado tem como fundamento o corpo, no sentido em que "a condição humana é corporal. Há uma conceituação de corpo, da mesma maneira que há um arraigamento carnal do pensamento" (LE BRETON, 2007, p.190). Possibilidades de pensar o corpo a existência - totalmente apartadas da carne escapam de nosso escopo. "Como a língua, o corpo é uma medida do mundo" (LE BRETON, 2007, p.190). No mascaramento, a singularidade de cada corpo envolve o coletivo e também a linguagem.

Tal como a filosofia umbuntu, a experiência com a máscara leva em conta o outro como corpo coletivo. Compartilhar fazeres, como, por exemplo, reunir em roda, ativa o coletivo, não se tratando apenas de um aspecto formal, mas de um dizer enviado a uma construção que perpassa todos os indivíduos. Umbuntu propõe uma pessoa que se constitui por meio de outras, exercendo um compartilhamento que conecta a humanidade. Diz-se que uma pessoa com umbuntu está aberta ao outro. Esse é o Orixá, o ancestral, a família, a aldeia, os elementos da natureza, tecendo uma paisagem que envolve o divino (mundo dos deuses), a comunidade (mundo dos seres humanos) e a natureza (mundo dos seres animados e inanimados). O pertencimento a esses três mundos possibilita a abertura que conecta o corpo. Desse modo, máscara e umbuntu são aberturas ao outro que perpassa o coletivo. Pode-se afirmar que a máscara visa ao pertencimento. As máscaras são relativas a cada corpo, a cada pessoa e, ao mesmo tempo, envolvem o coletivo. É esse mundo único que não pode ser habitado por

\footnotetext{
${ }^{6}$ Anotação colhida durante workshops, sob a orientação de Yoshito Ohono, realizados em 2013, em Tóquio.
} 
ninguém, apenas por aquele que o veste. Portanto, o mascaramento trata desse corpo único (utópico) de cada qual.

\begin{abstract}
Não haverá mais ninguém como nós quando nós tivermos ido embora, mas é um fato que não há no mundo ninguém igual a outra pessoa, nunca. Quando alguém morre, não existe um substituto possível. Cada um deixa um vazio que não pode ser preenchido, pois é o destino - genético e neural - de cada humano ser um indivíduo único, que deve achar seu próprio caminho, viver sua própria vida, morrer sua própria morte. (SACKS, 2015, p.3).
\end{abstract}

Por fim, experienciar a máscara - o mascaramento - será sempre um ato inaugural, sempre atuando na diferença, será viver a sua própria vida e a sua própria morte.

\title{
Bibliografia
}

AGAMBEN, Giorgio. Profanações. São Paulo: Boitempo, 2007.

Notas sobre o gesto. Artefilosofia, Ouro Preto, n. 4, p. 9-14, 2008.

O que é o contemporâneo e outros ensaios. Chapecó: Argos, 2009.

BAKHTIN, Mikhail. A cultura popular na Idade Média e no Renascimento: o contexto de François Rabelais. Trad. Yara Frateschi Vieira. São Paulo: Hucitec, 1987.

Hacia una filosofía del ato ético. De los borradores y otros escritos. Trad. y notas: Tatiana Bubnova. Barcelona/San Juan: Anthropos/EDUPR, 1977.

BAUDRILLARD, Jean. Senhas. Trad. Maria Helena Kühner. Rio de Janeiro: Difel, 2007.

De la seducción. Madrid: Ediciones Cátedra, 1981.

BUCHBINDER, Mário. A poética do desmascaramento. São Paulo: Agora, 1996.

CALVINO, Ítalo. Seis propostas para o próximo milênio. Trad. Ivo Barroso. São Paulo: Cia das Letras, 1990.

CLARK, Lygia, PEDROSA, Mário \& GULLAR, Ferreira. Lygia Clark. Rio de Janeiro: Funarte, 1980.

DIÉGUEZ, Ileana. Anotação de uma aula, em 11 de dezembro de 2014, durante a disciplina "Cenários Expandidos", ministrada por Ileana Dieguez, no Programa de Pós-graduação em Artes Cênicas da Escola de Comunicações e Artes da Universidade de São Paulo (ECA/USP).

FOUCAULT, Michel. O corpo utópico. (1966) Disponível em: http://www.ihu.unisinos.br/noticias/38572-o-corpo-utopico-texto-inedito-demichel-foucault>. Acesso em: ago. 2015.

HARAWAY, Donna. Manifesto Ciborgue. Ciência, Tecnologia e Feminismo Socialista no final do Século XX. In: TOMAZ, Tadeu (Org.). Antropologia do Ciborgue. As vertigens do pós-humano. Belo Horizonte: Autêntica Editora, 2009, p. 33-118..

ITO, Toyo. Escritos. Murcia: Colegio Oficial de Aparejadores y Arquitectos Tecnicos/Librería Yerba/Cajamurcia, 2000. 
JUNG, Carl Gustav. Consciência, Consciente e Individuação. In: Os Arquétipos e o Inconsciente Coletivo. Petrópolis: Vozes, 2002, p.267-282

LE BRETON, David. Adeus ao Corpo. Papirus: Campinas, 2007.

MATURANA, Humberto. Emoções e linguagem na educação e na política. Belo Horizonte: Editora UFMG, 1998.

MISKOLCI, Richard. Teoria Queer: um aprendizado pelas diferenças. Belo Horizonte: Autêntica Editora/UFOP, 2012.

PRECIADO, Paul Beatriz. O que é a contrassexualidade? 2015. Disponível em: <https://territoriosdefilosofia.wordpress.com/2015/05/05/o-que-e-acontrassexualidade-paul-beatriz-preciado/>. Acesso em: mai. 2015.

OHNO, Yoshito. Anotação colhida durante workshops, sob a orientação de Yoshito Ohno, realizados em 2013, em Tóquio.

OVÍDIO. Metamorfoses. In: CARVALHO, Raimundo. Metamorfose em tradução. São Paulo, Relatório de Pós-doutoramento FFLCH-USP, 2010.

SACKS, Oliver. Minha vida. O neurologista diante da morte. Folha de São Paulo (Ilustríssima), 22 fev. 2015, p. 3.

SANCHEZ, José Antônio. Dramaturgia en el campo expandido. In: BELISCO, M.; CIFUENTES, M. J.; \& ECIJA, A.; Repensar la dramaturgia/Rethinking Dramaturgy. Madrid: Centro de Documentación y Estudios Avanzados de Arte CENDEAC, 2011, p-19-36.

VIVEIROS DE CASTRO, Eduardo. A inconstância da alma selvagem. São Paulo: Cosac \& Naify, 2002.

ZEAMI, Nosakusho. In: MASAKUZU, Yamazaki (Org.). On the art of no drama. The major treatises of Zeami. Trad. J. Thomas Rimer. Princeton: Princeton University Press, 1984.

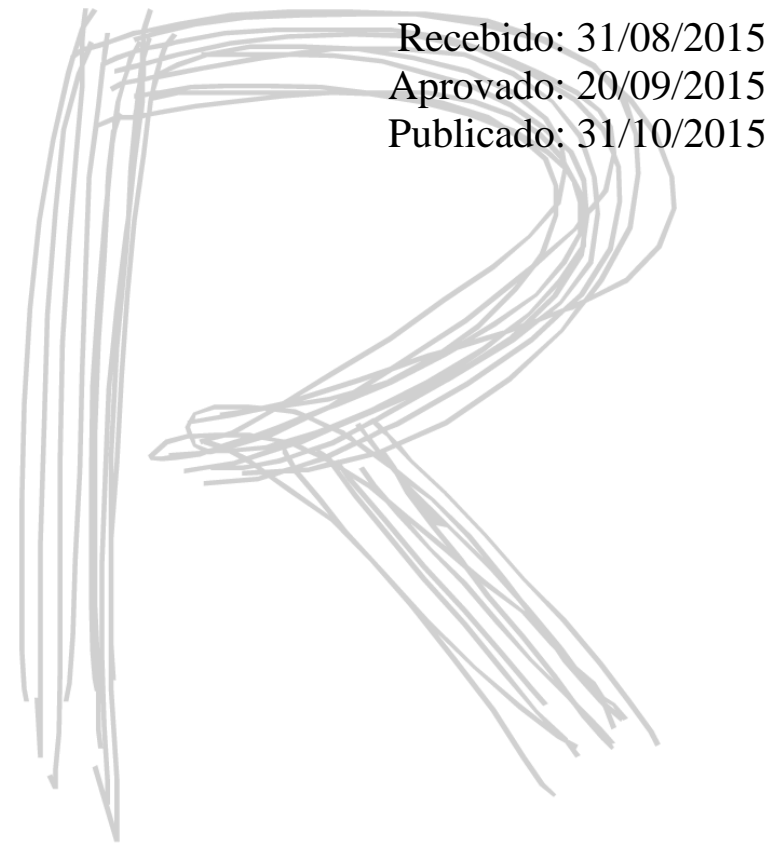

